\title{
Pemikiran Muthahhari tentang Manusia Masa Depan sebagai Subyek Dakwah
}

\author{
Irfan Sanusi \\ UIN Sunan Gunung Djati Bandung \\ E-mail: irfansanusirasyidi@yahoo.com
}

\begin{abstract}
This paper departed from Muthahhari's statement that human nature in Islam is paradoxical creatures. In itself there are good qualities and have a tendency to go towards the truths and sacred entities, and the nature of evil as well. All of this is the potential of the human being and should establish itself to become a more perfect self. In view Muthahhari, man as the vicegerent of Allah on earth and as the preaching subjects in which have the nature of God confess, free reliable. Humans as subjects of da'wah initiated the tendency towards good and evil, with their capacity that is not limited, having a whole and instinctive dignity, human driving motivation in many ways is not only material but is transcendent (divine) that finally can freely make use of the grace and gifts bestowed him that will shape the future humans as subjects propaganda bright, awakened, has theistic and spiritual freedom and not experiencing alienation of the self, the world and God.
\end{abstract}

\section{Kata Kunci:}

Subyek Dakwah, Makhluk Serba Dimensi, Kebajikan etis, Kebebasan Theistik

\section{A. Pendahuluan}

Murtadha Muthahhari (1920-1979 M), yang selanjutnya disebut Muthahhari, adalah seorang pemikir filosofis dan ulama yang begitu besar pengaruhnya terhadap perkembangan pembaharuan pemikiran Islam di Iran. Latar belakang pendidikannya sebagian besar diikuti di pusat pendidikan Qum, tempat yang banyak melahirkan ulama dan intelektual. Pendidikan yang diikutinya kebanyakan adalah masalah 
filsafat. Pada tahun 1952 Muthahhari meninggalkan Qum menuju Teheran dan menjadi dosen di Universitas Teheran (Bagir, 1988: 28-39).

Selain aktif di kampus, Muthahhari banyak menyampaikan ceramah-ceramah keagamaan di kalangan para pemuda dan aktifitasnya ini berupaya untuk merespon atau memberikan tanggapan atas pertanyaan-pertanyaan yang muncul di kalangan mereka sekitar masalah agama. Muthahhari pernah mengatakan bahwa dua puluh tahun ini, setiap saya akan menulis buku atau makalah, yang saya tuju hanyalah satu yaitu memecahkan kemusykilan-kemusykilan dan menjawab pertanyaan-pertanyaan pokok persoalan Islam pada zaman modern (Muthahhari, 1992: 11).

Islam yang dihadapi Muthahhari secara riil dan langsung adalah masyarakat Iran, yang situasi dan kondisinya dapat digambarkan sebagai berikut: salah satu kemalangan kita ini adalah karena kita berdiam di suatu negara yang ekonominya tidak dipusatkan pada landasan sosial yang kokoh (Muthahhari, 1992: 13). Masyarakat pada saat itu dilukiskan sebagai masyarakat yang menjauhi kebudayaannya yang asli dan menjelma menjadi sebuah masyarakat yang memiliki dan mengalami metamorfosis (perubahan bentuk) dan kehilangan identitas. Pusat keagamaan kehilangan efektifitasnya. Slogan kolonial tentang pemisahan agama dari politik mulai mengakar dalam masyarakat. Universitas menjadi asing dari agama. Kebudayaan barat yang mendominasi masyarakat menyebabkan munculnya gerakan-gerakan menyimpang, sehingga tersebarlah ideologi-ideologi asing seperti Marxisme dan Eksistensialisme, gerakan-gerakan nasionalisme dan peniruan, bahkan Freudisme yang mengajarkan kebebasan seksual (Bagir, 1988: 53-55).

Dalam situasi seperti ini, Muthahhari terjun ke medan kegiatan dakwah, segera Muthahhari memahami bahwa tidaklah mungkin menanggulangi keadaan ini kecuali dengan meruntuhkan dasar ideologis dan filosofis serta kebudayaan barat yang mendominasi. Dengan kejeniusan pemikirannya, Muthahhari menawarkan Islam sebagai alternatif yang disampaikannya melalui dakwah-dakwah dan karyakarya gemilangnya yang sudah dibukukan yang sebagian besar membahas tentang teologi dan filsafat.

Dalam filsafat manusianya, Muthahhari mengkritik konsep manusia para filosof barat, dan ketika ia mengecam moralitas baru, ia tidak berhenti sampai disana. Di atas reruntuhan filsafat manusia barat (eropa), Muthahhari manampilkan konsep al-Qur'an tentang manusia. 
Muthahhari merenungkan manusia tidaklah semata-mata al-Qur'an menyuruhnya. "dan tentang manusia mengapa tak kau renungkan" (Q.S. 51: 21). Ia merenungkan manusia untuk mencerahkan, menyadarkan dan membawanya hidup dalam sistem ilahiah yang luhur. Inilah yang Muthahhari sajikan dalam konsep manusia masa depannya. Dan karena ia mengetahui bahwa bencana yang melanda manusia modern sekarang adalah ketidaktahuan manusia tentang dirinya (Rakhmat dalam Muthahhari, 1986: 27).

\section{B. Keberadaan Manusia sebagai Subyek Dakwah}

\section{Kodrat Manusia}

Masalah ada tidaknya kodrat manusia merupakan masalah yang penuh kontroversi dikalangan para filosof dari dulu hingga kini. Sartre menggugat konsep kodrat dan mengatakan "seandainya pun memiliki kodrat, maka esensi manusia tidak mungkin ditentukan, tapi terbuka sekali" (Kaufman, 1975: 349). Menurut Van der Weij, pemikiran Sartre dapat dipahami sebagai berikut: kemungkinan ultim manusia adalah mewujudkan esensinya. Akan tetapi esensi itu baru dapat diketahui serta dilukiskan setelah manusia itu mati (Van der Weij, 1991: 151-154).

Penolakan Sartre terhadap konsep kodrat terutama dalam pengertian kodrat sebagai sesuatu yang telah dikonsepsikan oleh Tuhan dalam rencana penciptaan. Jadi yang dimaksud kodrat dalam hal ini adalah kodrat manusia dalam hubungannya dengan Tuhan Yang Maha Kuasa lagi Maha Mengetahui. Pandangan ini menurut Sartre terutama dianut oleh para filosof theistis sebagai konsekuensi dari kepercayaan mereka (Kaufman, 1975-348).

Bagi Muthahhari (1986: 43) di satu pihak menolak pandangan yang menganggap bahwa manusia sama sekali tidak memiliki esensi, namun dipihak lain dia beranggapan bahwa kodrat manusia tidak dapat didefinisikan karena sifatnya yang tidak terbatas. Muthahhari menguraikan pandangannya dengan argumentasi berikut : ketiadaan mutlak esensi hanya mungkin dua kasus. Pertama, wujud atau ada yang dimaksud tersebut memiliki kesempurnaan yang tak terhingga dan aktualitas yang tak terbatas yaitu wujud tersebut meliputi seluruh ruang dan waktu dan mengatasi segala wujud lainnya dan ini tidak lain daripada wujud Sang Pencipta itu sendiri. Bagi wujud yang demikian itu gerak dan pertumbuhan adalah mustahil, karena gerak dan perkembangan 
menunjukan adanya kekurangan atau ketidak-sempurnaan, sementara wujud tersebut mustahil memiliki kekurangan apapun. Kedua, hal itu dapat diberlakukan pada wujud yang kosong dari bentuk aktualitas apapun yaitu dia sepenuhnya merupakan posibilitas belaka, suatu tangga ketiadaan, adanya diperbatasan terjauh dari eksistensi, kosong dari segala realitas dan esensi bawaan, walaupun sanggup menerima setiap bentuk maupun esensi. Wujud demikian dengan sendirinya mutlak tidak beresensi. Inilah yang disebut sebagai "Materi Pertama" oleh sebagian filosof. Dia menempati kedudukan terendah di dalam hierarki eksistensi dan berada paling ujung terjauh keberadaan, sebagaimana zat ilahi berada di ujung lainnya. Perbedaannya adalah bahwa kutub yang ditempati oleh zat Ilahi meliputi semua ada.

Manusia sebagaimana makhluk lainnya, disituasikan diantara kedua ujung tersebut yang berlainan. Pernyataan al-Qur'an bahwa manusia adalah gabungan dari roh Allah dan tanah lempung merupakan simbolisasi dari kenyataan ini, keduanya memperlambangkan kemungkinan-kemungkinan tak terbatas yang ada dihadapan manusia. Manusia dengan kehendak bebasnya menjalani tugasnya sebagai makhluk belum jadi untuk membentuk diri dan masa depannya.

Kepada manusia ditawarkan dua jalan: ketaqwaan dan kefasikan dan diberi kemampuan inheren dalam dirinya untuk membedakan yang baik dari yang jahat. Lalu kepadanya dikirimkan para utusan untuk mengingatkan mereka akan tujuan penciptaan mereka.

Perbedaan manusia dengan makhluk lainnya adalah bahwa perjalanan manusia menuju kesempurnaan tidak mengenal batas, sementara makhluk lainnya terikat pada suatu batasan tertentu yang tak dapat mereka lampaui. Tiada titik akhir dari kemungkinan perkembangan manusia.

Pada akhirnya menurut Muthahhari manusia sebagai subyek dakwah memiliki suatu jenis keberadaan tertentu, tapi berbeda dengan pandangan para filosof yang percaya akan kelebihdahuluan esensi atas eksistensi dan mereduksi segala sesuatu kepada esensinya dan menolak kemungkinan perubahan esensial sebagai sesuatu yang berlawanan. Muthahhari berpendapat bahwa kodrat eksistensial manusia sebagai subyek dakwah-sebagaimana benda materi lainnya-adalah perubahan, dengan perbedaan dari benda lainnya bahwa gerakan dan perubahannya tidak mengenal batas akhir (Muthahhari, 1986:49). 
Manusia sebagai subyek dakwah menurut Muthahhari adalah tipe eksistensi yang tak alami, memperoleh sifatnya sesuai dengan pilihannya sendiri. Kesadaran jenis ini benar-benar ditegakkan di atas prinsip bahwa manusia dianggap sebagai satu unit nyata. Dan ini semua bersumber dari kepemilikan manusia, yaitu sejenis esensi tertentu yang biasa disebut fitrah manusia. Akar kata fitrah adalah $f$-t- $r$ yang berarti menciptakan. Fitrah adalah nama lain dari Tuhan yang juga mengandung arti pencipta. Fitrah mempunyai kaitan yang erat dengan tujuan penciptaan, sedangkan tujuan penciptaan itu sendiri merujuk kepada potensi-potensi, bakatbakat dan kemungkinan-kemungkinan apa saja yang iheren pada diri manusia. Atau bentuk-bentuk kesempurnaan apa saja yang mungkin bagi manusia. Potensi-potensi ini tidak dengan sendirinya teraktualisasikan pada diri manusia, sebagaimana pada makhluk-makhluk lainnya tetapi kebebasan manusia itu sendirilah yang menentukan esensinya melalui amal perbuatannya. Selanjutnya dapat dikatakan bahwa esensi seseorang adalah hasil akhir dari suatu proses aktualisasi diri. Dalam konteks ini Muthahhari memperkenalkan apa yang disebut proses metamorfosis, yaitu suatu proses dimana seseorang mengalami degradasi (kepribadian) menjadi binatang atau bahkan lebih rendah (Muthahhari, 1986: 166).

Pada akhirnya kodrat atau esensi manusia sebagai subyek dakwah menurut Muthahhari dapat dipahami dalam dua pengertian: pertama, yaitu kodrat sebagai potensi bakat dan kesempurnaan apa saja yang mungkin bagi manusia, ini berkaitan dengan fitrah atau tujuan penciptaan manusia. Dengan kata lain, hal ini juga menyangkut ideal kemanusiaan-idea sering kali diartikan sama dengan esensi-atau diri ideal manusia, karena sebagaimana yang telah dinyatakan sebelumnya bahwa kodrat eksistensial manusia adalah perubahan yang tidak mengenal batas akhir, maka konsekuensinya adalah bahwa diri ideal manusia adalah sesuatu yang tak terbatas, ini merujuk kepada Tuhan. Pengertian kodrat disini lebih bersifat fungsional. Kedua, kodrat sebagai hasil akhir dari proses pembentukan diri manusia. Ini dapat disebut sebagai kodrat dalam pengertian substansial.

Selanjutnya untuk membentuk satu "kita" tunggal dari semua manusia dan menghembuskan jiwa yang menyatu ke dalam dirinya untuk mengubah moral dan pesona insaninya adalah "kesatuan iman" dan bukan "kesatuan substansi" didalam penciptaan. Yang nyata dan sekaligus ideal adalah kesatuan dari manusia-manusia an-sich yang telah 
mencapai kemanusiaan dan yang pantas menjadi manusia. Dalam hal ini Nabi Muhammad Saw menunjuk orang-orang bertaqwa sebagai anggota dari tubuh yang satu, bukan manusia-manusia 'anak Adam' secara keseluruhan. Sebagaimana sabda Nabi:

"Orang-orang yang beriman laksana anggota-anggota tubuh yang satu. Ketika salah satu anggota tubuh dirundung sakit, yang lain merasa bersimpati, melibatkan diri mereka dalam derita dan merasa tidak nyenyak tidur." (HR. Turmudzi).

Tak ragu lagi bahwa manusia seperti di atas akan ramah terhadap semua manusia dan segala bentuk makhluk. Mereka bersikap ramah bahkan kepada manusia-manusia yang telah termetamorfosiskan.

\section{Perbedaan Manusia dan Hewan}

Apakah karakteristik yang membedakan manusia dari hewan? beberapa pemikir menyangkal adanya suatu perbedaan yang mendasar antara keduanya dan menganggapnya hanya sebagai perbedaan yang bersifat kuantitatif atau paling-paling kualitatif, namun tidak esensial (Muthahhari, 1986: 66). Pandangan ini di anut antara lain Hobbes, Freud dan Skinner. Perbedaan antara manusia dengan binatang kurang lebih sama dengan perbedaan-perbedaan yang ada di antara binatang itu sendiri, oleh karena itu manusia disejajarkan dengan binatang. Sementara dipihak lain sejumlah pemikir lainnya memandang bahwa manusia memiliki perbedaan esensial dengan binatang yang oleh karenanya manusia menempati tingkat eksistensi tersendiri dalam alam maujud ini. ada sesuatu yang baru sama sekali dan bersifat tambahan bukan sekedar perkembangan lebih lanjut dari unsur yang ada pada binatang. Schumacher menyebutnya sebagai sesuatu 'ketaksinambungan ontologik' atau secara lebih sederhana disebut sebagai sesuatu lompatan di dalam tingkat eksistensi (Schumacher, 1981: 18).

Perbedaan-perbedaan dasar antara manusia dan makhluk lainnya, yang menjadi dasar kemanusiaannya, sumber dari apa yang dinamakan sebagai peradaban dan kebudayaan manusia adalah maujudnya apa yang disebut wawasan dan kepercayaan. Menurut Muthahhari, binatang pada umumnya dapat mencirikan diri dari lingkungannya dan berjuang untuk mencapai keinginan dan tujuan dengan bimbingan kesadaran dan pengenalannya. Begitu pula manusia, hanya dia berbeda dengan binatang dalam jangkauan, keluasan dan tingkat kesadaran serta 
pengenalannya. Inilah yang memberikan kelebihan, keunggulan serta membedakan dirinya dari semua hewan yang lain (Muthahhari, 1986: 62).

Pertama, kesadaran binatang akan lingkungannya sepenuhnya diperoleh melalui indera-indera luarnya, dan oleh karena itu bersifat luaran (eksternal) dan dangkal, tidak menjangkau esensi dan seluk beluk objek kesadaran. Kedua, bersifat individual dan khusus, tanpa kemampuan menggeneralisasikannya. Ketiga, bersifat lokal dan terbatas pada lingkungannya saja. Keempat, bersifat langsung atau segera, terbatas pada masa kini, tercerai dari masa lalu dan masa depan. Binatang tidak sadar akan sejarah dirinya maupun dunia dan tidak menganggap ataupun mengaitkan perjuangannya dengan masa depan. Dengan demikian binatang dipagar penjara rangkap empat. Kalaupun mereka secara kebetulan melampauinya, hal itu terjadi tanpa kesadaran dengan intelegensi ataupun pilihan, melainkan terperangkap dalam paksaan alam, secara naluriah dan tanpa kesadaran ataupun penalaran (Muthahhari, 1986: 63).

Tingkat hasrat dan tujuan binatang juga terbatas, hal ini dikarenakan: pertama, ia bersifat badani atau material belaka, tidak lebih dari sekedar makan, minum, tidur, bermain, bersarang dan kopulasi. Bagi binatang tidak ada masalah dengan hasrat-hasrat dan tujuan-tujuan abstrak, nilai-nilai moral. Kedua, bersifat pribadi dan individual, berhubungan dengan dirinya atau paling-paling dengan pasangannya dan anak-anaknya. Ketiga, terlokalisasi dan terkait lingkungannya, Keempat, bersifat langsung dan terikat pada kekinian. Jika seekor binatang mengejar sasaran atau bergerak menuju suatu tujuan yang melampaui batasan-batasan tersebut, misalnya dia menunjukkan concern pada spesiesnya lebih dari sekedar individu atau kepada masa depan lebih dari sekedar kekinian, sebagaimana yang teramati pada hewan-hewan sosial seperti lebah madu, maka prilaku tersebut lahir tanpa disadari dan bersifat naluriah belaka (Muthahhari, 1986: 63-64).

Baik dalam wilayah kesadaran, wawasan dan tujuannya, pengenalan ataupun keinginan-keinginan, kemampuan manusia jauh melampaui apa yang ada pada binatang. Kesadaran dan pengenalan manusia melewati dan mengatasi batas-batas eksterior dari objek dan fenomena menembus bagian dalamnya, esensi dan hakikatnya, saling terkait dan tergantung serta kebutuhan-kebutuhan yang mengarahkan mereka. Kesadaran manusia tidaklah tinggal terkurung dalam batas- 
batas ruang dan waktu, dia menjelajah melalui ruang dan waktu (Muthahhari, 1986: 138-139). Kesadaran manusia terus meningkat, mulai dengan mengungkapkan sejarah masa lalu dirinya maupun alam semesta, sampai kepada merenungkan masa depan kehidupannya.

Ditinjau dari sudut hasrat-hasrat dan tujuan-tujuannya, manusia juga mampu mencapai suatu tingkat yang tinggi. Muthahhari mengungkapkan bahwa manusia adalah makhluk yang mencari nilainilai dan mendambakan kebajikan dan ideal-ideal yang tidak bersifat material atau sekedar mencari keuntungan. Hasrat-hasratnya tidaklah bersifat untuk dirinya atau keluarganya, tapi juga bersifat umum, meliputi dan mencakup keseluruhan kemanusiaan, tidak terbatas pada suatu lingkungan atau periode waktu tertentu. Sedemikian terikatnya manusia pada ideal-ideal dan kepercayaannya itu sehingga kadangkadang ia menempatkannya diatas segala yang lainnya.

Keunggulan-keunggulan manusia yang disebut di atas bukanlah sesuatu yang wujud begitu saja pada manusia, namun berproses dan berevolusi dengan bersumber atau bertolak dari sifat kehewanannya. Prinsip ini berlaku baik pada individu maupun masyarakat. Pada mulanya manusia hanyalah sekedar suatu tubuh fisik; melalui suatu evolusi esensial, ia menjadi suatu substansi rohani. Manusia lahir dari dalam buaian tubuh, dimana dia berevolusi dan berkembang menuju kebebasan. Aspek kehewanan manusia betindak sebagai sarang di dalam aspek kemanusiaan berevolusi dan tumbuh. Adalah suatu menjadi sifat evolusi bahwa semakin berkembang suatu organisme maka semakin tinggi tingkat kebebasan, kemandirian dan kemam-puannya menguasai lingkungan. Semakin berkembang kemanusiaan manusia, baik dalam tingkat individu maupun masyarakat maka semakin mengarah dia kepada kebebasan dan penguasaan atas aspek-aspek lain dari wujudnya. Semakin sempurna suatu individu maka semakin meningkat penguasaannya atas lingkungan internal maupun eksternalnya. Individu yang sempurna adalah individu yang telah terbebaskan dari dominasi lingkungan internal maupun eksternalnya tetapi mengikatkan diri pada suatu keimanan (Muthahhari, 1986: 68).

Perkembangan aspek kemanusiaan manusia sebagai subyek dakwah ditentukan oleh iman dan ilmu yang merupakan kriteria kemampuannya. Iman dan ilmu sangat berperan menentukan kesadaran, wawasan dan tujuan hidup manusia. 


\section{Manusia sebagai Subyek Dakwah: Makhluk Serba Dimensi}

Perbedaan manusia dengan binatang dapat ditelusuri lebih lanjut dengan menunjukkan dimensi-dimensi manusia. Para filosof berbeda pendapat tentang jumlah dimensi manusia, ada yang berpendapat bahwa manusia hanya dimensi satu, yang lainnya berpendapat bahwa manusia adalah makhluk multi dimensi. Muthahhari menolak pandangan yang mereduksi manusia menjadi makhluk satu dimensi. Pandangan materialisme sejarah dan determinisme sejarah merupakan salah satu contoh dari pandangan yang menganut prinsip bahwa manusia hanya memiliki satu dimensi. Penganjur teori ini percaya bahwa faktor utama dan prinsip yang membentuk sejarah, dalam setiap masa adalah ekonomi. Menurut teori ini, faktor-faktor produksi, distribusi kekayaan dan hubungan-hubungan kerja menentukan aspek-aspek kehidupan lainnya seperti agama, filsafat, sains, hukum, etika dan seni. Pada awalnya teori ini menciptakan kegemparan, namun dewasa ini ia sudah tidak berlaku dan kehilangan keabsahannya, bahkan sebagian besar pemikir materialis pun menolak teori tersebut (Muthahhari, t.th.: 49).

Sebuah potret manusia sebagai makhluk jasmaniah dan rohaniah yang memiliki sejumlah kesamaan dengan binatang; akan tetapi pada saat yang sama dipisahkan dari jenis makhluk hewani tersebut dengan jurang perbedaan yang mendasar. Dalam hal-hal yang sama dimiliki manusia dan binatang, misalnya indera-indera fisik, sejumlah binatang tertentu lebih unggul ketimbang manusia. Namun keunggulan tersebut tetap bersifat dangkal dan tidak menukik ke dasar dan hakikat bendabenda, maupun hubungan logis antar benda. Sedangkan manusia dengan potensi akal pikirannya mampu memahami diri dan alam sampai sedetildetilnya, seluk beluk serta hakekatnya. Contoh lainnya, berkenaan dengan hasrat dan kebutuhan-kebutuhan yang sama menarik dengan binatang, seperti makan, istirahat, kopulasi dan lain-lain, tetapi bagi manusia ada pesona-pesona lain yang memandu mereka menuju tujuantujuan non materi dan tak mungkin dinilai dengan kriteria duniawi (Muthahhari, 1986: 125-126).

Muthahhari mengungkapkan bahwa diantara dimensi-dimensi manusia, yang berkaitan bahkan merupakan pengejawantahan dari keistimewaan manusia sebagai subyek dakwah, antara lain a) Ilmu dan pengetahuan b) Kebajikan etis c) Etestika dan keindahan d) pemujaan atau pengkudusan e) Keserbabisaan Manusia dan f) Pengetahuan tentang diri dan pengembangan bakat. 
Ilmu dan Pengetahuan: kegandrungan manusia akan ilmu pengetahuan tidaklah semata untuk menaklukkan alam dan memakmurkan kehidupan lahiriahnya belaka. Lebih dari itu, mereka didorong oleh suatu naluri untuk mencari dan menemukan kebenaran, yang memungkinkan pengetahuan itu bermanfaat sebagai alat untuk memperbaiki kehidupan dan menunaikan tanggung jawab, ia sematamata merupakan ideal yang dibutuhkan oleh rasa ingin tahu itu sendiri. Sebagai contoh, manusia mesti mengungkapkan rahasia dibalik galaksigalaksi; dan tidak sola apakah pengetahuan tentang ia akan mempengaruhi kehidupan mereka atau tidak, mereka tetap ingin memperoleh informasi yang berkenan dengannya. Hal ini menunjukkan bahwa manusia secara naluriah senantiasa cenderung belajar dan mencari pengetahuan (Muthahhari, 1986: 126).

Sedangkan sumber pengetahuan dan kebenaran itu menurut Imam Ghazali yaitu; pertama, Syar'i yakni yang diperoleh dari al-Qur'an dan asSunnah, dan kedua adalah intelektual yang diperoleh dari akal pikiran. Kedua sumber ini tidak bisa dipisahkan, karena bagi mereka yang mengetahuinya kebanyakan dari pengetahuan syar'i adalah aqli, dan bagi mereka yang mengerti, kebanyakan dari pengetahuan aqli adalah syar'i (Othman, 1987, 75-76).

Kebajikan etis: Dalam melakukan tindakan-tindakannya, manusia lebih dipengaruhi oleh serangkaian emosi etis daripada oleh keinginan untuk memperoleh keuntungan atau untuk menghindari bencana. Manusia percaya bahwa peri-kemanusiaan mestilah ditunjukan dengan tindakan-tindakan seperti itu. Pepatah mengatakan bahwa kebajikan mesti dibalas dengan kebajikan atau pernyataan al-Qur'an : tidak ada balasan bagi kebaikan kecuali kebaikan pula (Q.S. 55 : 60). Merupakan seruan hati nurani yang mencuat dari suatu kesadaran moral. Hal itu merupakan salah satu aspek ruhaniah manusia yang tidak dimiliki oleh makhluk lainnya (Muthahhari, 1986 : 127).

Etestika dan Keindahan: keindahan merupakan bagian integral dari eksistensi manusia dan memepengaruhi seluruh aspek kehidupannya. Ini dapat terlihat dari pakaian dan rumah, bukan hanya dari segi fungsionalnya saja yang diperhatikan tapi juga faktor kindahannya, seperti pemilihan jenis warna dan motif hiasan. Manusia menghendaki kota dan jalan-jalan yang elok, pemandangan yang indah. Secara universal manusia senantiasa cenderung untuk mewujudkan sentuhan 
keindahan pada setiap segi kehidupannya. Keindahan sama sekali tidak berperan dalam kehidupan binatang (Muthahhari, 1986 : 128).

Pemujaan dan Pengkudusan: keduanya merupakan pengejawantahan yang paling mendasar dan berulang kali muncul dalam jiwa manusia, karena merupakan dimensi yang prinsipil dalam hidup seseorang. Suatu studi terhadap peninggalan-peninggalan peradaban manusia, mengungkapkan pemujaan dan sembahyang senantiasa mendampingi kemunculan umat manusia di bumi. Tetapi bentuk-bentuk pemujaan dan jenis tuhannya senantiasa berubah dari bentuk-bentuk yang paling primitif sampai kepada yang paling maju.

Menurut kebanyakan ajaran agama, dan khususnya menurut pandangan para teolog seperti Max Muller, manusia pada hakekatnya bersifat monotheis. Sejak semula manusia sudah menyembah Tuhan yang sejati. Pada kenyataannya, manusia tidaklah berawal dari menyembah berhala, sesama manusia, atau makhluk-makhluk lain, dan kemudian secara bertahap menuju monotheisme seiring dengan perkembangan peradaban. Penyembahan yang bisa dimaksudkan sebagai keadaan religius, maujud pada tiap-tiap diri manusia. Penyembahan bagi manusia menuntut suatu loncatan dari diri terbatasnya ke arah penyatuan dengan suatu realitas tanpa cacat, batasan dan kematian. Sebagaimana diungkapkan oleh Albert Einstein: "(dengan menyembah hakikat ini) seseorang akan merasakan kehampaan hasrat dan keinginan manusia. Ia akan merasakan sublimitas dan tatanan agung yang menampakkan diri, baik di alam semesta maupun di alam pemikiran (Muthahhari, 1986: 130). Masalah ini kemudian dibahas lebih lanjut oleh Iqbal yang berpendapat bahwa penyembahan merupakan suatu ibadah umum yang vital, dengannya pulau kecil karakter kita akan menemukan posisinya dalam suatu keseluruhan yang lebih luas (Iqbal, 1968 : 105106).

Berdoa dan bersembahyang mengejawantahkan eksistensi suatu "potensialitas" atau suatu "hasrat" manusia, kemampuan untuk menjangkau suatu tempat diluar alam material, dan hasrat untuk menguasai cakrawala yang lebih tinggi dan luas. Hasrat ini merupakan ciri seluruh umat manusia, itulah sebabnya mengapa pemujaan dan pengkudusan membentuk dimensi spiritual manusia (Muthahhari, 1986:131).

Kemudian setelah manusia memenuhi hasratnya tersebut, akan ada suatu masa dimana kebutuhan untuk membentuk pribadinya kepada dimensi spiritual lainnya. Seperti halnya berusaha untuk menjalankan 
segala perintah Tuhan dan menjauhi yang dilarang-Nya, pribadi seperti ini adalah pribadi yang berpredikat taqwa, dalam arti taqwa dalam membentuk kepribadian manusia mempunyai dimensi yang luas seperti, menjaga diri, menyelamatkan diri, membentengi diri dari berbagai akibat buruk dan kejahatan yang destruktif. Sikapnya terbuka, tak ada ketakutan apapun yang sempat menggoyahkan keseimbangan mentalnya. Tanpa ada rasa ragu, sebab ia sadar sepenuhnya apapun adanya yang terlahir maupun yang tersimpan dan tak pernah lolos dari tangkapan Kemahatahuan Tuhan. Allah juga lebih dekat dari urat leher manusia itu sendiri, kepada-Nya lah titik pusat kiblat hatinya. Dan itulah yang mampu menempa pribadinya, tidak pernah minder, cemas atau rasa rendah diri terhadap siapapun kecuali hanya kepada Tuhan (M. Husain Rifa'i Hamzah, tt:230-231).

Keserba-bisaan Manusia : Kuasa atau daya didefinisikan sebagai faktor yang menghasilkan pengaruh yang dimiliki oleh sesuatu. Sepanjang suatu makhluk dapat dianggap sebagai sumber dari suatu atau berbagai pengaruh, tak soal apakah ia berupa objek tak hidup, tetumbuhan, ataupun hewan, ia memiliki kuasa atau daya. Jika kuasa kemudian dipadukan dengan kecerdasan dan pemahaman, ia akan menjadi 'potensi' atau 'kapabilitas' (Muthahhari, 1986:131).

Manusia sebagai subyek dakwah mampu menyetujui atau melawan keinginan-dalamnya dan mampu menyalahi kehendak dirinya. Oleh karena itu mereka dapat bertindak atas dasar kuasa iradah yang ada dibawah komando kearifan dan intelek mereka - kearifan akan mengenali dan memberi keputusan, sedangkan kuasa-iradah akan mewujudkannya. Manusia dapat menjadikan nafsunya patuh terhadap kehendaknya sehingga manusia dapat mencapai kebebasan 'spiritual, suatu kebebasan yang paling bernilai disbanding kebebasan lainnya. Kecenderungan nafsu manusia bertalian pusat eksternal yang menariknya. Semakin kuat manusia menghamba kepada nafsu, semakin lemah tak berdaya dan semakin lemah tujuan manusia. Sebaliknya intelek dan kuasa kehendak merupakan daya-daya internal yang membangun karakter sejati kemanusiaan. Jika manusia menyandarkan diri pada kedunya, maka manusia akan mampu menguasai dan mengembangkan potensi-potensinya, menahan pengaruh eksternal, dan membentuk diri manusia menjadi pulau yang merdeka, sehingga berubah menjadi 'pemilik dirinya', pemilik dari suatu karakter paripurna. Pengendalian dan pembebasan diri dari pesona nafsu merupakan tujuan 
fundamental ajaran Islam. Tujuan Utama ajaran ini adalah "kemerdekaan spiritual" (Muthahhari, 1986 : 132-133).

Pengetahuan tentang Diri : Manusia berbeda dengan binatang, memiliki kemampuan untuk mengenal diri dan membimbingnya ke arah 'diri' sejati. Dengan pengetahuan yang sempurna tentang diri, manusia akan dapat merasakan suatu martabat dan derajat, menjauhi kehinaan, mengenali kesucian diri, serta paham akan makna dan nilai kesucian sosial maupun etis (Muthahhari, 1986 : 133).

Manusia diciptakan sebagai khalifah Tuhan di muka bumi. Alam semesta diciptakan untuk manusia dan hakikat kekhalifahan itu sendiri adalah pemimpin di muka bumi yang berkewajiban untuk menyebarkan kemakmuran di dunia, menyusun dan mengembangkan segenap potensi alam, menaklukan dan menguasai serta mengatur dengan sebaik-baiknya sesuai dengan kehendak serta yang telah digariskan oleh sang pencipta (M. Husain Rifa'i Hamzah, tt:71). Malaikat bersujud dihadapannya. Hal ini memberikan pengaruh psikologis dan edukatif bagi orang yang mempercayainya, sedangkan mempercayai bahwa manusia merupakan produk dari kebetulan yang tak bertujuan tentu akan membuahkan pengaruh lain. Memahami diri berarti memahami bahwa manusia tidak hanya tertancap di bumi, memahami bahwa manusia merupakan nur Ruh Ilahi, bahwa mereka mampu mengalahkan para melaikat dalam hal kearifan, dan bahwa manusia itu merdeka, mampu menghidupi diri dan bertanggungjawab pada sesama manusia serta pada kemakmuran dan perbaikan dunia (Muthahhari, 1986 : 134).

Pengembangan Bakat: dimensi khusus manusia lainnya sebagai subyek dakwah adalah kemampuannya untuk mengembangkan bakat. Ajaran Islam memberikan perhatian yang seimbang kepada seluruh dimensi manusia; fisik dan mental, material dan spiritual, rasional sosial dan individual. Ia memberikan perhatian istimewa pada latihan dari masing-masing dimensi dalam konteksnya yang relavan dan atas dasar prinsip-prinsip tertentu, yaitu latihan fisik dan spiritual. Latihan fisik meliputi antara lain mencegah dari pengumbaran nafsu, memelihara kesehatan diri secara seksama, mencegah diri dari perbuatan-perbuatan yang membahayakan tubuh. Latihan spiritual antara lain latihan bagi intelek dan mengembangkan akal yang akan melahirkan kemerdekaan berfikir, serta perjuangan melawan apapun yang menghalangi kemerdekaan ini, seperti peniruan membuta terhadap para leluhur, dan mengikuti mayoritas (Muthahhari, $1986: 135-136$ ). 
Manusia sebagai subyek dakwah pada hakekatnya harus bebas untuk menjelmakan moralitas dan cita-cita moral. Untuk menjelmakan cita-cita moral, manusia harus bebas tidak hanya untuk memilih niat-niat yang saling bertentangan di dalam hatinya, tapi juga untuk berjuang dalam situasi sosial untuk mengubah dunia, hubungan-hubungan manusia menjadi suatu masyarakat moral di dalam menghadapi pertentangan yang sedang berkecamuk (Ansari, 1983: 304).

\section{Manusia Masa Depan Sebagai Subyek Dakwah}

Manusia diciptakan untuk menjadi makhluk yang berakal sadar, bebas dan bertanggungjawab. Dari hari pertama ketika manusia mencapai tahapan kemanusiaan tanpa memperhatikan kapan hal itu terjadi - ia menjadi pembantu dan wakil tuhan. Tidak ada waktu sejak saat penciptaan manusia sejak bumi ada, tanpa kemaujudan seorang khalifah, kesaksian dari Allah, yaitu makhluk yang dianugerahi kebebasan, dan tanggung jawab. Semua itu menjadi bekal manusia untuk dapat membedakan antara kebaikan dan kejahatan (Muthahhari, 1991: 50).

Manusia masa depan sebagai subyek dakwah menurut Muthahhari didasari oleh prinsip Islam yang berusaha untuk membuat keseimbangan antara dua aspek manusia yang tinggi dan yang rendah serta melekat pada watak manusia. Tindakan-tindakan yang diperintahkan berupa penyembahan dan pantangan-pantangan dari dosa. Semuanya, disamping nilai sosial dari ajaran tersebut secara mendasar didesain untuk menumbuhkan aspek kemanusiaan manusia dan membangkitkan kemanusiaannya. Oleh karena itu, jika manusia sungguh-sungguh ingin mengambil suatu langkah dalam arah evolusi ini, tidak ada alternatif untuk menumbuhkan semua kriteria dan ide materialistik tentang watak manusia di atas, yaitu manusia harus dianggap sebagai makhluk yang mengatasi ide-ide perbedaan kelas dan masyarakat tanpa kelas. Hanya dengan demikian perjuangan manusia dapat mempunyai karakter ideologi yang hakiki dengan didasarkan pada iman dan keyakinan (Muthahhari, 1991: 51).

Dalam tulisan ini membahas tentang manusia masa depan sebagai subyek dakwah menurut Muthahhari, yang mempunyai kriteria-kriteria sebagai berikut: kebebasan theistik yang mutlak, dengan pandangan eksistensialis, khususnya Sartre sebagai pembanding, kebebasan rohani 
Irfan Sanusi: Pemikiran Murtadha Muthahhari tentang Manusia Masa Depan...

yang menjadi kebutuhan, sebagai tujuan utama penyempurnaan manusia; serta ketidakterasingan akan diri, Tuhan dan dunia.

\section{Kebebasan Theistik yang Mutlak}

Aliran eksistensialis menyelamatkan kebebasan dan kehormatan manusia dari belenggu naturalisme dan materialisme klasik, serta dialektika materialisme dan oleh semua itu manusia bisa membumbung tinggi dan bisa berdiri diatas kedua telapak kaki iradahnya yang otomatis bebas, tapi tiba-tiba untuk kesekian kalinya manusia membenturkan kepalanya pada kekosongan yang gelap, dan pada determinismedeterminisme yang naturalis-dialektis, yang tidak memiliki kesadaran atau menempatkan dirinya pada tempat diatasnya, namun dalam bentuk yang kosong tanpa makna, tanpa tujuan. Kehilangan seluruh nilai kemanusiaannya yang bebas dan luhur serta dalam bentuknya yang lebih cepat dan kejam (Ali Syari'ati, 1992 : 76-77).

Menurut Sartre (Bertens, 1987:167), kebebasan merupakan ciri khas manusia, semakin bebas manusia maka semakin sempurna ia. Semakin efektif pengaruh-pengaruh eksternal atas manusia semakin berkurang kemanusiaannya. Bahkan lebih jauh lagi, Sartre mengajukan konsep kebebasan mutlak sebagai kriteria kemanusiaannya dan menolak segala bentuk keterikatan sebagai suatu yang mengasingkan manusia. Kemanusiaan juga berarti pemberontakan terhadap segala sesuatu, ciri 'menindak-penindakan' dari kebebasan.

Kemudian bagi Sartre keberadaan manusiawi hanya atas dasar suatu kebebasan total yang mencipta, karena kebebasan adalah kemungkinan untuk 'penindakan'. Jika manusia adalah kebebasan yang mencipta secara total, maka ia menyempurnakan dirinya sendiri, ia adalah suatu rancangan untuk masa mendatang. Jadi kodrat (esensi) manusia tidak mungkin ditentukan tapi terbuka sekali. Dengan sendirinya eksistensi akhirnya mendahului esensi manusia. Ia mengakui bahwa manusia menerima adanya Tuhan, mempunyai pandangan lain dan dalam hal ini bahkan konsekuen, karena jika ada Tuhan yang Maha Tahu serta Maha Kuasa, maka segalanya yang bukan Tuhan adalah Ciptaan-Nya. Oleh karena itu dalam diri Tuhan sudah ada rencana penciptaan di mana esensi benda-benda - juga esensi manusia - telah ditentukan. Seorang manusia tidak dapat berubah secara hakiki dan tidak dapat mencapai taraf lebih tinggi dari yang ditentukan Tuhan. Pada akhirnya bagi Sartre esensi (yang ideal) mendahului eksistensi ; 
eksistensi hanya boleh dianggap perkembangan dan pengkhususan dari esensi itu (P.A. Van der Weij, 1991: 151).

Muthahhari (dalam Gimples of the Nahj al Balaghah pada Jurnal al Tauhid, 1986: 35) menjawab argumen Sartre dengan mengatakan bahwa keterlekatan manusia kepada Tuhan tidaklah dapat disamakan dengan keterlekatan manusia dengan objek-objek selain-Nya. Islam sepenuhnya menerima pandangan bahwa keterlekatan manusia kepada sesuatu akan mengakibatkan stagnasi atau kemandegan perkembangan pribadi. Penolakan terhadap segala sesuatu mau tak mau diakhiri dengan suatu penerimaan. Kebebasan manusia tersituasikan dalam pilihan-pilihan yang harus diputuskan. Keputusan kebebasan manusia tidak hanya berciri 'penindakan' sebagaimana yang dipahami Sartre, tetapi sekaligus berciri 'pengiyaan' . penindakan yang manusia lakukan kepada sesuatu, bagaimanapun, akhirnya harus berakhir dengan pengiyaan terhadap pilihan kita. Sudah menjadi sifat alami maujud, bahwa segala sesuatu hanya dapat bertahan selama padanya berlaku daya tarik dan daya tolak. Setiap partikel, wujud atas dasar keseimbangan daya tersebut.

Kebebasan, dalam arti keterlepasan, adalah sekaligus keterikatan. Dengan kata lain kebebasan 'dari'-kebebasan dalam arti negatif-selalu mengimplikasikan kebebasan 'untuk' - kebebasan dalam arti positif. Jadi kebebasan dengan ciri menindak semata dan pemberontakan sebagai esensi adalah sesuatu yang menjurus kepada nihilisme atau anarki. Kebebasan mutlak, yaitu kebebasan tanpa komitmen atau keterikatan sama sekali adalah mustahil (Hasan, 1985: 94-95).

Islam menyeru manusia untuk melepaskan diri dari segala bentuk keterlekatan kepada segala sesuatu kecuali kepada Tuhan. Hal ini didasarkan pada penolakan pengabdian kepada segala sesuatu kecuali Tuhan dan tunduk patuh hanya kepadaNya. Islam yang berarti pasrah atau tunduk kepadaNya justru menjadi pangkal kebebasan kaum muslim dan sumber energi manusia yang hebat. Oleh karena itu untuk masyarakat manusia pada umumnya, proses pembebasan itu tidak lain adalah pemurnian kepercayaan kepada Tuhan yang Maha Esa itu sendiri dan terdiri dari dua langkah yaitu pertama dengan melepaskan diri dari kepercayaan kepada yang palsu dan kedua dengan pemusatan kepercayaan hanya kepada yang benar (Madjid, 1992:80).

Menurut Muthahhari dalam masalah ini ada dua hal yang harus diketahui yaitu: pertama, bahwa Tuhan merupakan sesuatu yang tak terbatas sedangkan yang lainnya terbatas. Keterlekatan kepada sesuatu 
yang terbatas mengakibatkan kemandegan atau stagnasi, dan mengakibatkan metamorfose, sedangkan keterlekatan dengan Tuhan yang tak terbatas tidak bersifat demikian. Keterlekatan manusia kepada Tuhan bukanlah sejenis keterlekatan sesuau kepada bukan dirinya (non self) sehingga keterlekatannya menyebabkan seseorang lupa akan dirinya, melainkan keterlekatan sesuatu yang merupakan sumber kamujudannya, raison d'etre atau akar keberadaannya, yang dekat kepada dirinya lebih dari bagian-bagian esensi dirinya sendiri.

Tuhan berfirman: "Kami lebih dekat kepadanya daripada urat lehernya,..." (Q.S. 50:16) dan “...Ketahuilah bahwa Allah melindungi antara manusia dan hatinya...” (Q.S. 8:24). Dengan kata lain tidak hanya kesadaran Tuhan akan dirinya, bahkan "Zat kami lebih dekat kepadamu dari engkau kepada dirimu sendiri..." hal ini menurut Muthahhari merupakan konsep Qur'ani yang sublim. Khalifah Ali r.a. berkata : .... Tuhan tidaklah ada didalam atau dari suatu objek, dan dia tidaklah terpisah dan terlepas darinya...." (Ali Bin Abi Thalib, 1993: 22). Kedua, alQur'an menyembutkan bahwa manusia harus merasakan suatu keterlekatan dan kecenderungan kepada Tuhan, karena Tuhan merupakan titik akhir perjalanan manusia. Kecintaan manusia kepada Tuhan tidak lain dari kecintaan kepada manusia pada dirinya yang paling sempurna. Gerak manusia menuju Tuhan adalah gerak menuju kepada dirinya sendiri dari suatu diri yang belum sempurna menuju suatu diri yang lebih sempurna (Muthahhari, 1989:12).

\section{Kebebasan Rohani}

Pembahasan ini dibatasi pada analisis terhadap jenis kebebasan yaitu: kebebasan sosial dan kebebasan rohani. Alasan pemilihan tema ini terutama karena menurut Muthahhari bahwa akar dari banyak masalah yang dihadapi manusia modern antara lain disebabkan oleh penekanan yang berlebihan pada kebebasan sosial dengan mengabaikan kebebasan rohani dan semua ini akan mengalami kekeringan dan kekosongan aspek kejiwaan sehingga yang ada hanya kegelisahan (Muthahhari, 1983:37 \& 46).

Kebebasan, dalam konteks ini terutama dalam pengertian tiadanya rintangan dalam perjalanan mansia menuju kesempurnaan. Manusia adalah makhluk yang khusus dan kompleks, selain memiliki kehidupan pribadi jua memiliki kehidupan sosial. Oleh karena itu, pembicaraan mengenai kebebasan dapat ditinjau dari aspek sosial maupun aspek individu. Kebebasan sosial dalam hal ini terutama dimaksudkan sebagai 
kebebasan yang dimiliki manusia dalam hubungannya dengan individuindividu lain dalam masyarakat, atau dengan perkataan lain kebebasan dari segala bentuk keterikatan, penghambaan, perbudakan, dan eksploitasi dari sesama manusia. Kebebasan rohani adalah kebebasan seseorang dari dirinya sendiri, diri yang dimaksud disini adalah diri hewaniah seseorang (Muthahhari, 1983: 37-38).

Menurut Muthahhari manusia sebagai subyek dakwah memiliki dua diri atau ego, yaitu ego diri manusiawi dan diri hewani. Diri hewani manusia antara lain meliputi kecenderungan hawa manusia seperti keserakahan, kecintaan terhadap harta benda egosime. Kebebasan rohani dapat diartikan sebagai kebebasan diri manusiawi dari diri hewaninya.

Kebebasan sosial akan kehilangan maknanya apabila tidak disertai kebebasan rohani. Hanya kebebasan rohani yang mampu, secara hakiki, mencegah seseorang yang berkuasa memanfaatkan kekuasaannya untuk menguasai dan memperbudak sesama manusia dan tujuan eksplisit dari pengutusan para nabi adalah mewujudkan kebebasan sosial dan membebaskan manusia dari perbudakan timbal-balik. Seperti diungkapkan dalam al-Qur'an surat Ali Imran ayat 64 :

Katakanlah: "Hai Ahli Kitab, marilah (berpegang) kepada suatu kalimat (ketetapan) yang tidak ada perselisihan antara kami dan kamu, bahwa tidak kita sembah kecuali Allah dan tidak kita persekutukan Dia dengan sesuatupun dan tidak (pula) sebagian kita menjadikan sebagian yang lain sebagai tuhan selain Allah." Jika mereka berpaling maka katakanlah kepada mereka: "Saksikanlah, bahwa kami adalah orang-orang yang berserah diri (kepada Allah)."

Ayat diatas menurut Muthahhari mengandung pengertian, pertama, penolakan segala bentuk sesembahan kecuali kepada Tuhan, dan kedua, penghapusan penolakan segala bentuk eksploitasi atas sesama manusia. Jadi kebebasan sosial merupakan sesuatu yang utama dan suci, namun demikian misi para nabi tidaklah terbatas pada perwujudan kebebasan sosial tapi juga untuk mewujudkan kebebasan rohani pada masing-masing individu dan kebebasan rohani hanya mungkin terwujud melalui proses kenabian dan para nabi, melalui iman dan kitab-kitab suci, melalui kesalehan, ibadah dan penyucian jiwa yang didasarkan pada keimanan (Muthahhari, 1983: 25 dan 46). 


\section{Penempatan Manusia Sebagai Subyek Dakwah pada Takdirnya}

Penolakan manusia terhadap eksistensi Tuhan sering kali didasarkan pada pandangan yang keliru terhadap konsepsi takdir Tuhan. Tapi bagi Islam sikap pasrah kepada Tuhan dan takdirNya merupakan ajaran yang positif. Bukan ajaran yang menghendaki kepada manusia menjadi fatalistis. Namun dalam kenyataannya cukup banyak sikap fatalistis di lingkungan umat manusia dewasa ini. manusia menganggap tidak ada gunanya mengembangkan prakarsa dan insiatif, oleh karena berpendapat bahwa semuanya sudah diatur oleh Tuhan Yang Maha Kuasa. Kehidupan menjadi pasif tanpa dinamika yang memungkinkan kemajuan (Nurcholis, 1994: 564).

Bentuk-bentuk pelarian seperti ini merupakan sesuatu yang tercela, bahkan terkutuk, dalam agama. Hal ini merupakan suatu bentuk rasionalisasi yang membekukan perkembangan kepribadian seseorang. Sikap seperti ini disebut juga sebagai sikap inotentik atau bad faith. Dengan variasi-variasi tertentu, sipa demikian juga diamati pada orangorang beragama yang menjadikan Tuhan sebagai tempat pelarian dari kebebasan mereka (Bertens, 1987: 170-171).

Masalah kebebasan dan ikhtiar merupakan salah satu diantara masalah-masalah filosofis yang amat pelik dan rumit sejak abad pertama hijrah serta telah menjadi perbedaan pendapat dikalangan pemikir muslim. Pembahasan-pembahasan tersebut seringkali dilakukan dengan bertitik tolak dari sudut pandang filosofis maupun teologis semata. Akibatnya aspek praktis dan sosialnya terabaikan (Muthahhari, 1986: 182-183).

Takdir menurut Muthahhari mengandung dua konsep terpisah yaitu: qadha dan qadar. Qadha berarti penetapan hukum, atau pemutusan dan penghakiman sesuatu. Qadar berarti kadar atau ukuran tertentu. Kejadian-kejadian alam, ditinjau dari sudut keberadaannya di bawah pengawasan dan kehendak Allah, dapat dikelompokkan ke dalam qadha ilahi, dan dari sudut sifatnya yang terbatas pada ukuran tertentu serta pada kedudukannya pada ruang dan waktu, dapat dikelompokkan ke dalam qadar ilahi. Qadha dan qadar tidak memiliki arti lain kecuali terbinanya sistem sebab akibat umum atas dasar pengetahuan dan kehendak ilahi (Muthahhari, 1986: 198 \& 202).

Allah menciptakan hukum untuk alam yang tidak mungkin suatu perbuatan dapat dilakukan bertentangan dengannya. Sebagaimana halnya dengan kejadian-kejadian alam yang tidak akan terjadi tanpa 
sebab-sebab alamiah, maka perbuatan-perbuatan ikhtiar manusia pun tidak akan terjadi tanpa kehendak manusia dan tanpa ikthiarnya. Dengan demikian hukum Allah yang berkaitan dengan manusia adalah bahwa manusia merupakan makhluk yang memiliki kehendak dan ikhtiar. Manusialah yang memilih perbuatan baik dan buruk. Karena ikthiarnya merupakan salahsatu tonggak eksistensi manusia, maka mustahil ada manusia yang tidak memiliki ikhtiar. Asumsi adanya manusia yang tidak memiliki ikhtiar adalah asumsi yang khayali dan tidak realistis. Kalau ia bukan manusia, maka ia tidak kena kewajiban, seperti binatang sapi dan keledai. Sebagaimana halnya dengan qadha dan qadar Allah menghendaki terciptanya manusia, maka qadha dan qadar-Nya pun menghendaki manusia memiliki kebebasan dan ikhtiar (Muthahhari, 1992:114).

Sistem inilah yang mendasari tata tertib semesta yang didalamnya manusia menjalankan kebebasannya. Adanya sistem kausalitas inilah yang memungkinkan manusia untuk mengembangkan pengetahuannya, baik ilmu-ilmu alam maupun ilmu-ilmu kemanusiaan. Dengan meningkatnya pengetahuan manusia tentang diri dan alam semesta, semakin besar peluang kebebasan yang dimilikinya dan semakin ia mampu mengatasi hambatan internal maupun eksternal dalam perjalanannya menuju kesempurnaan. Takdir, dengan demikian tidaklah dapat diartikan sebagai kekuatan membuta yang telah menentukan perjalanan (nasib) manusia dari semenjak azali. Pembahasan ini diakhiri dengan ungkapan Muthahhari bahwa ilmu Allah dapat mengalami perubahan, dalam arti bahwa Allah mempunyai suatu pengetahuan tertentu yang dapat mengalami perubahan. Hukum (keputusan) Allah dapat mengalami pembatalan, dalam arti bahwa Allah memiliki beberapa hukum yang memang dapat mengalami pembatalan. Dan bahwa yang rendah adakalanya mempengaruhi yang tinggi, dan bahwa sistem alam bawah, terutama kehendak dan perbuatan manusia, bahkan kehendak manusia semata-mata, adakalanya dapat 'menguncangkan' alam atas dan menyebabkan beberapa perubahan padanya. Inilah kekuasaan tertinggi manusia atas nasibnya (Muthahhari, 1986: 209).

\section{Ketidakterasingan diri dan Tuhan}

Keterangan diri dan Tuhan merupakan dua hal yang tidak terpisahkan. Keterasingan diri mengandaikan adanya suatu 'diri'; yang kepadanya manusia mengalami keterasingan. Apakah perubahan dan evolusi atau perkembangan diri yang dialami manusia harus 
menyebabkan keterasingan dari dirinya? atau mestikah manusia mempertahankan diri dari segala perubahan dan evolusi demi mencegah keterasingan?

Menurut Muthahhari evolusi sejati setiap manusia sebagai subyek dakwah adalah suatu gerak maju tingkat dari tingkat kesempurnaan yang sesuai dengan fitrahnya. Dengan kata lain, transformasi selama seseorang berada diatas jalan yang lurus fitrahnya sama sekali tidak menyebabkan kehilangan identitas. Karena yang membentuk diri sejati dari suatu wujud adalah eksistensinya, bukan esensinya. Jadi setiap perubahan dari 'diri' menuju suatu 'bukan diri', Mulla Sadra merupakan penggagas filsafat eksistensialisme Islam, berpendapat bahwa manusia tidaklah memiliki suatu esensi tertentu, bahkan dalam setiap perkembangannya melewati berbagai tingkat dalam evolusinya, manusia bukanlah sebagai makhluk satu jenis melainkan pluralis jenis. Jika manusia sadar akan dirinya dan tujuan evolusinya, maka tidak akan merasakan keterasingan diri (Muthahhari, 1986: 166).

Dalam konteks Islam sendiri disebutkan bahwa pengenalan dan penyadaran diri tidak dilepaskan dari hubungan dengan Tuhan. Upaya pengungkapan diri hanya mungkin diwujudkan melalui ibadah yang terdiri dari pikir dan dzikir. Pikir merupakan suatu upaya pendekatan analitis rasional terhadap realitas atau kebenaran, sedangkan dzikir merupakan suatu pendekatan holistik terhadap realitas kebenaran.

\section{Ketidakterasingan dari Dunia}

Beberapa aliran pemikiran cenderungan pesimis dalam memandang dunia. Menurut mereka tatanan semesta ini jauh dari sempurna dan memandang keberadaan manusia di dunia ini sebagai akibat dari suatu kesalahan kosmik, seakan-akan manusia itu nyasar kedalamnya. Manusia merupakan makhluk asing total di dunia, oleh karena itu tujuan utama manusia adalah mencari 'pelepasan' (Muthahhari, 1984:30).

Pandangan ini dapat ditemui pada sejumlah filosuf, diantaranya Plato, dan berbagai agama di dunia. Untuk selamat, kata Plato manusia harus memalingkan diri dari dunia dan pengaruh pikiran pada konsepkonsep matematika dan dialektika. Manusia tidak boleh merasa betah di dunia ini, manusia harus yakin akan kesemuan atau ketidaknyataan dunia ini dan meletakkan harapan kita kepada dunia lainnya yang berada dibalik segala pengalaman inderawi, dibalik perubahan dan waktu, yaitu 
apa yang disebut sebagai 'dunia ide' (P.A. Van der Weij, Terj. K. Bertens, 1991:19).

Menurut Muthahhari, hubungan manusia sebagai subyek dakwah dengan dunia adalah ibarat hubungan seorang petani dengan ladang atau sawahnya. Dunia ini adalah tempat dimana manusia melatih diri, dan mengembangkan potensi-potensi diri kemanusiaannya untuk mencapai kesempurnaan. Sebagaimana yang dikatakan Imam Ali ra :

Dunia adalah sahabat bagi yang berjalan bersamanya dengan cara yang bersahabat, ia adalah sumber kesembuhan bagi yang mengetahui hakikatnya. Dunia adalah tempat beribadah para pecinta Allah, tempat shalat malaikat Allah, tempat turunnya wahyu Allah dan tempat berniaga para wali Allah (Muthahhari, 1992: 171172).

Kehidupan akan berubah menjadi makmur manakala manusia mampu menguasai dunianya, tahu dan sadar sepenuhnya bahwa tugasnya dalam mengatur dunia sebagai sarana menuju kebahagiaan sejati dalam lindungan sang pencipta (keridhaan Allah) kelak dalam kehidupan sejati dan kekal abadi di akhirat. Dan manusia akan menemui kehancuran, terperosok ke dalam lembah kenistaan seandainya dunia menguasainya, diperhamba dan diperbudak oleh dunia. Semua ini lantaran memperturutkan hawa nafsu serakahnya, terbelenggu oleh kepicikan dan kebutaannya sendiri, sehingga dalam bayangannya dunia merupakan awal dan akhir tujuan hidupnya yang utama (M. Husain Rifa'i Hamzah, tt: 71-72). Itulah yang disebut dengan manusia yang terasing dari dunianya.

\section{Kesimpulan}

Pada bagian terakhir pembahasan ini dapat diambil kesimpulan sebagai berikut: bahwa manusia sebagai subyek dakwah menurut Muthahhari memiliki kodrat eksistensial yang bersifat terbuka dengan perubahan yang tidak mengenal batas akhir. Kodrat atau esensi manusia dipandang dari sudut tujuan penciptaan manusia tidaklah harus bertentangan dengan kebebasan manusia sebagaimana pendapat Sartre. Hal ini karena yang dimaksud dengan kodrat disini adalah potensipotensi atau kemungkinan ultim kemanusiaan yang aktualitasnya 
bergantung pada manusia itu sendiri. Cordite manusia bersifat terbuka dan tidak terbatas, maka Muthahhari menolak pandangan yang bersifat reduksionistik terhadap manusia dan tegas menyatakan bahwa manusia adalah makhluk multi dimensi. Muthahhari menyebutkan sejumlah dimensi atau ciri kemanusiaan, tanpa bermaksud membatasi seperti: pengetahuan, estetika, etika, pemujaan, kesadaran diri, keserbabisaan manusia dan pengembangan bakat. Karakteristik Utama yang membedakan manusia dengan hewan terletak pada fakta bahwa manusia memiliki pengetahuan dan keimanan yang masing-masing melahirkan kesadaran diri dan dunia dalam diri manusia. Melalui pengetahuan dan keimanan manusia membentuk kebudayaannya, maka manusia disebut makhluk yang berbudaya.

Manusia masa depan sebagai subyek dakwah tidak akan mengalami keterasingan, apabila manusia melestarikan sifat kemanusiaannya dan kemudian peduli terhadap Tuhan dan agama. Kemudian dalam memandang dan menempatkan, serta kecenderungannya terhadap dunia tidak keliru.[] 


\section{DAFTAR PUSTAKA}

Al-Ghazali. (1982). Mizan al A'mal. terj. Ali Hasan. Semarang: Toha Putra

Ali bin Abi Thalib. (1993). Mutiara Nahjul Balaghah. terj. Muhammad Bagir. Bandung: Mizan

Ali, Fachry. (1985). 'Realitas Manusia: Pandangan Sosiologi Ibnu Khaldun,' dalam Dawam Rahardjo (Penyunting), Insan Kamil Kon-sepsi Manusia Menurut Islam. Jakarta: Grafiti Press

Anshari, Muhammad Fazlur Rahman. (1983). Konsepsi Masyarakat Islam Modern. Bandung: Risalah

Bertens, K. (1987). Fenomenologi Eksistensialis. Jakarta: Gramedia

Danusiri. (1996). Epistemologi dalam Tasawuf Iqbal. Yogyakarta: Pustaka Pelajar

Fromm, Erich. (1987). Memiliki dan Menjadi. Terj. Soesiloharjo, Jakarta: LP3ES

Gazalba, Sidi. (1981). Sistematika Filsafat Buku IV. Jakarta: Bulan Bintang.

Hamzah, Muhammad Husain R, (t.th.). Potret Manusia Ankabutisme. Pustaka Progresif

Hasan, Ahmad Rifa'i. (2006). 'Manusia Serba Dimensi dalam Pandangan Morteza Muthahhari,' dalam M. Dawam Rahardjo (penyunting) Insan Kamil: Konsepsi Manusia Menurut Islam. Jakarta: Grafiti Press.

Hasan, Fuad. (1985). Berkenalan dengan Eksistensialisme. Jakarta: Pustaka Jaya

Khozin, Agus. (2004). Konsepsi Manusia Menurut Drijarkara. Skripsi. Bandung: Fakultas Ushuluddin IAIN Sunan Gunung Djati Bandung

Leahy, Louis. (1993). Manusia sebagai Sebuah Misteri. Jakarta: Gramedia

Ma'arif, Ahmad Syafi'i. (1993). Peta Bumi Intelektualisme Islam di Indonesia. Bandung: Mizan

Madjid, Nurcholis. (1992). Islam Doktrin dan Peradaban. Jakarta: Paramadina

Muthahhari, Murtadha. (1986). Perspektif Islam tentang Manusia dan Agama. Bandung: Mizan

(1987). Islam dan Kebahagiaan. terj. Alwiyah Abdurrahman. Bandung: Rosdakarya

Ilmu Dakwah : Academic Journal for Homiletic Studies Vol. 6 No. 1 | Juni 2012 
(1989). Pandangan Dunia Tauhid. terj. Agus Effendi. Bandung: Yayasan Muthahhari (1991). Falsafah Kenabian. terj. Ahsin Mohamad. Jakarta: Beunebi Cipta (1991). Menguak Masa Depan Umat Manusia: Suatu Pendekatan Sejarah. Haidar Bagir (pengantar). Jakarta: Pustaka Hidayah

. (1992a). Islam Agama Keadilan. terj. Agus Effendi. Jakarta: Pustaka Hidayah (1992b). Allah dalam Kehidupan Manusia. terj. Agus Effendi. Bandung: Mizan (1992c). Kritik Islam terhadap Faham Materialisme. terj. Achsin M. Muzdakir. Jakarta: Risalah Masa Jakarta: Lentera (1993). Manusia Sempurna. terj. M. Hashem, (1995). Masyarakat dan Sejarah. Terj. M. Hashem. Bandung: Mizan

Othman, Ali Issa. (1987). Manusia Menurut al-Ghazali. Bandung: Pustaka Syamsudin, Muhammad. (1997). Manusia dalam Pandangan K.H. Azhar Basyir, MA. Yogyakarta: Titian Ilahi Press

Syari'ati, Ali. (1992). Humanisme, Antara Islam dan Madzhab Barat. Bandung: Mizan

Tim Peneliti IAIN Syarif Hidayatullah. (1993). Manusia Berkualitas Menurut Islam. Jakarta: Pusat Penelitian IAIN Syarif Hidayatullah 